\title{
Child Neurology: Ethylmalonic encephalopathy
}

Periyasamy Govindaraj, PhD, Bindu Parayil Sankaran, FRACP, Madhu Nagappa, DM, Hanumanthapura R. Arvinda, DM, Sekar Deepha, MSc, J.N. Jessiena Ponmalar, MSc, Sanjib Sinha, DM, Narayanappa Gayathri, PhD, and Arun B. Taly, DM

Neurology ${ }^{\circledR}$ 2020;94:e1336-e1339. doi:10.1212/WNL.0000000000009144

Ethylmalonic encephalopathy (EE; OMIM \#602473) is an autosomal recessive disorder characterized by (1) progressive neurologic impairment, including global developmental delay with periods of regression during illness, progressive pyramidal and extrapyramidal signs, and seizures; and (2) generalized microvascular damage, including petechial purpura and chronic hemorrhagic diarrhea. It leads to premature death. $\mathrm{EE}$ is caused by mutations in ethylmalonic encephalopathy protein 1 (ETHE1), and more than 60 different mutations have been reported. ${ }^{1,2}$ ETHE1 encodes a mitochondrial sulfur dioxygenase involved in the catabolism of hydrogen sulfide $\left(\mathrm{H}_{2} \mathrm{~S}\right){ }^{2}$ Impairment of sulfur dioxygenase leads to the accumulation of hydrogen sulfide and its derivatives (thiosulphate) in various body fluids and tissues. Higher concentration of $\mathrm{H}_{2} \mathrm{~S}$ is toxic and induces direct damage to cell membranes. It inhibits cytochrome c oxidase (COX), increases lactic acid and short-chain acyl-COA dehydrogenase, and leads to elevation of ethyl malonate and C4/C5 acylcarnitine in muscle and brain. ${ }^{2}$ We describe the clinical phenotype and MRI, pathologic, and biochemical findings of a patient with EE from India who had a novel homozygous c.493 G>C (p.D165H) variation in ETHE1.

\section{Clinical case}

The proband was born to consanguineous parents (first cousins) during the eighth month of gestation (figure 1A). Postnatally, he required admission to the intensive care unit because of poor feeding and "sepsis." He attained early developmental milestones on time. At 7 months, he developed vomiting, altered sensorium, generalized seizures, and global regression following a febrile illness. He had hyperammonemia $(179.7 \mu \mathrm{mol} / \mathrm{L}$; reference range: 16-60 $\mu \mathrm{mol} / \mathrm{L})$. Brain MRI showed altered signals in the dorsal pons, which were hyperintense in T2-weighted imaging and isointense on fluid-attenuated inversion recovery. He was treated with antibiotics, antiviral and antimalarial agents, and anticonvulsants, along with IV immunoglobulin based on the presumed diagnosis of acute disseminated encephalomyelitis, and he recovered gradually. From 3 years and 10 months of age, he gradually regressed in all domains. At the time of first evaluation at our center at 52 months of age, he had head circumference of $48 \mathrm{~cm}$ (3rd centile), height of $87 \mathrm{~cm}$ ( $<3$ rd centile), and weight of $10.2 \mathrm{~kg}(<3 \mathrm{rd}$ centile) and skin rash (figure 1B). Ocular fundi were normal. There were contractures at hamstrings and tendo-Achilles and generalized spasticity, exaggerated stretch reflexes, and extensor plantar responses along with involuntary movements in the form of dystonia, with a component of chorea (video 1).

Elevated serum lactate was observed on multiple occasions (38.2, 42.7, and 53.4; reference range: $4.5-20 \mathrm{mg} / \mathrm{dL})$, while serum ammonia was mildly elevated on 2 occasions $(58.0,71.0,74.0 \mu \mathrm{mol} /$ $\mathrm{L}$; reference range: $16-60 \mu \mathrm{mol} / \mathrm{L})$. Screening for inborn errors of metabolism showed normal amino acids and acylcarnitine profile. Gas chromatography-mass spectrometry for organic acids in urine carried out on 2 occasions showed normal results at 4 years of age and mild elevation of ethylmalonic acid (EMA) (4.5-fold) at 5 years of age (figure e-1A, doi.org/10.5061/dryad. $6 \mathrm{c} 9 \mathrm{~h} 1 \mathrm{k} 7)$. The patient received anticonvulsant (levetiracetam), antispasticity agent (baclofen), biotin, carnitine, coenzyme $\mathrm{Q}$, and multivitamins. During follow-up, he made interim developmental progress (figure 1A). Serial MRIs of the brain between 11 months and 5 years of age are depicted in figure $1 \mathrm{C}$.
Correspondence

Dr. Parayil Sankaran

Bindu.parayilsankaran@

health.nsw.gov.au

MORE ONLINE

○ Video

From the Departments of Neuropathology (P.G., S.D., N.G.), Neurology (B.P.S., M.N., S.S., A.B.T.), Neuroimaging and Interventional Radiology (H.R.A.), and Neuromuscular Laboratory-Neurobiology Research Centre (P.G., B.P.S., M.N., S.D., J.N.J.P., N.G., A.B.T.), National Institute of Mental Health and Neurosciences, Bengaluru, India.

Go to Neurology.org/N for full disclosures. Funding information and disclosures deemed relevant by the authors, if any, are provided at the end of the article. 
Figure 1 Clinical features and MRI, pathologic, biochemical, and genetic observations in a patient with ethylmalonic encephalopathy

A

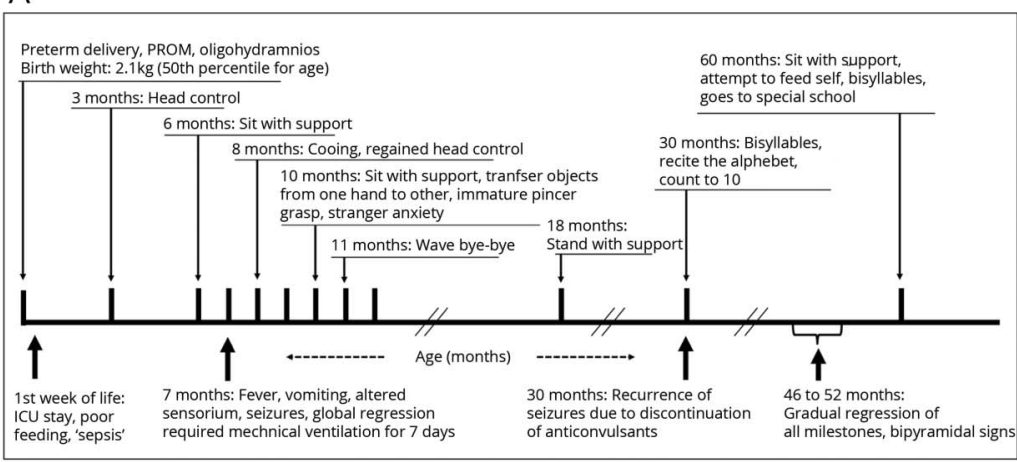

B

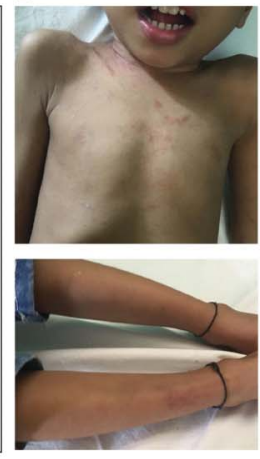

C T2W FLAIR DWI ADC Postcontrast T1
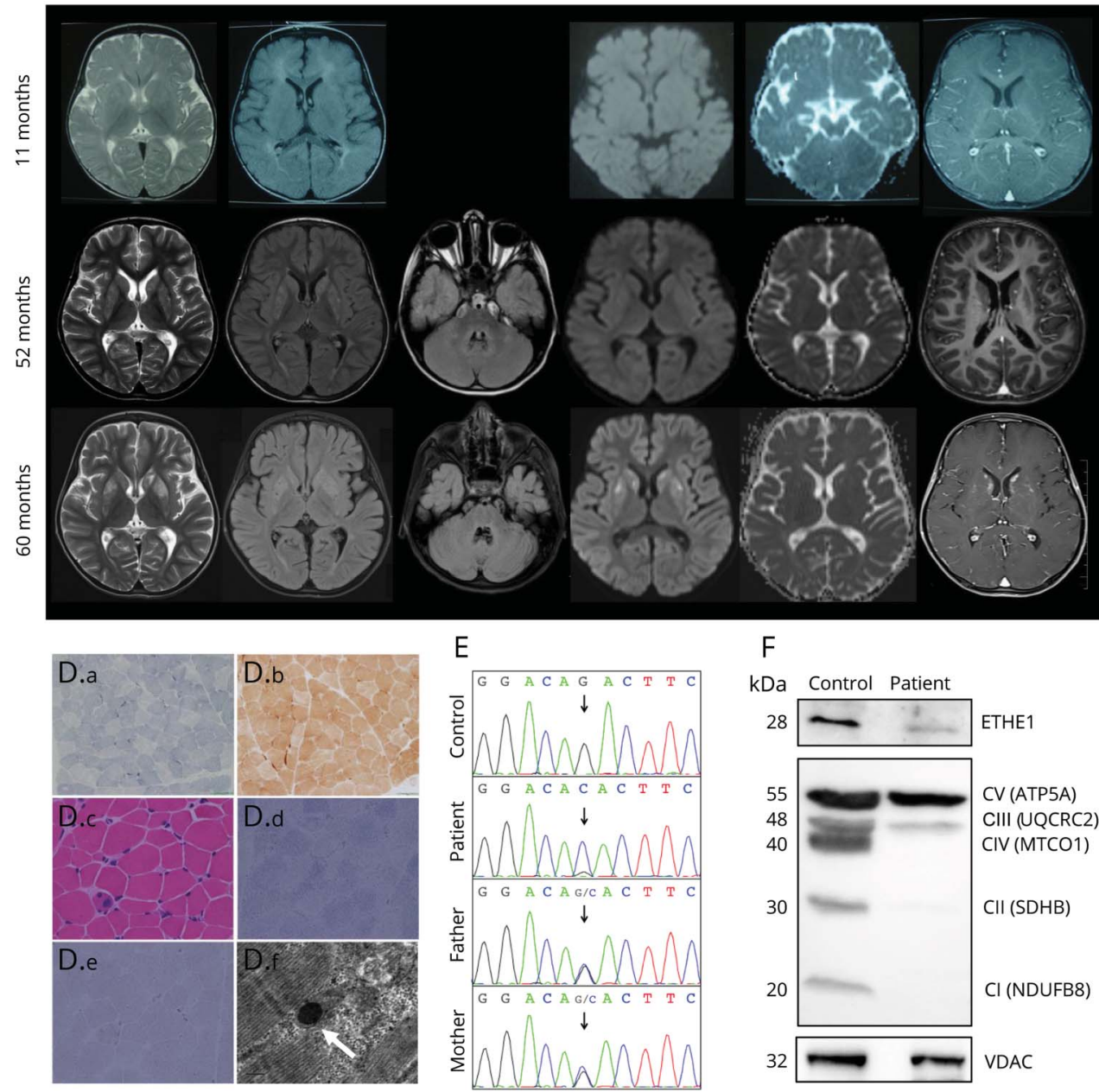

$\mathrm{F}$

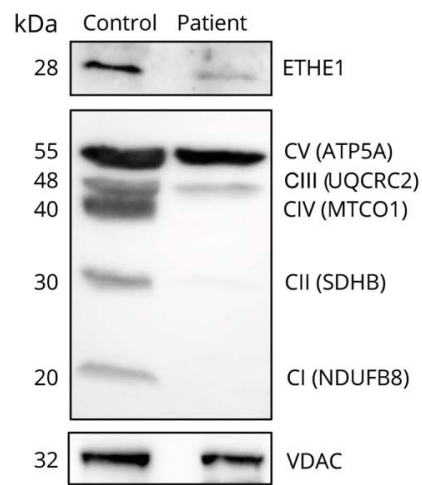

(A) Schematic representation of the clinical course. (B) Patchy erythematous skin rash over the trunk and extremities. (C) Axial sections of brain MRI show ill-defined areas of altered signal intensity in the periventricular region, adjacent frontal horns, and atria of lateral ventricles bilaterally with mild paucity of white matter at 11 months of age. At 52 months, brain MRI shows bilaterally symmetrical, patchy hyperintensity in caudate and putamina, without evidence of diffusion restriction or bleed and subtle hyperintensity in the dorsal pons. A small focus of enhancement is noted in the right caudate head. Bilaterally symmetrical hyperintensity is also noted in the periventricular white matter. Brain MRI at 60 months of age shows the persistence of hyperintensity in caudate and putamina and subtle hyperintensity in the dorsal pons. The extent and intensity of enhancement in postcontrast sequences has increased. (D) Transversely cut skeletal muscle tissue shows (a) normal succinate dehydrogenase $(\mathrm{SDH})(\times 200)$ and $(\mathrm{b})$ normal cytochrome c oxidase (COX)-SDH $(\times 200)$ staining pattern; (c) sections from biopsy show mild variation in fiber size on hematoxylin \& eosin stain $(\times 200)$ and $(d, e)$ SDH and COX-SDH reveal reduced intensity $(\times 200)$. (f) Electron microscopy shows electron-dense structure in the mitochondria (arrow; $\times 12,000)$. (E) Sequence electropherogram of c.493 G>C variation shows (arrow) wild-type in control, homozygous mutant in patient, and heterozygous in father and mother. (F) Western blot analysis of skeletal muscle extracts of ETHE1 protein shows a very low level of expression in the patient compared to control; OXPHOS complex I, II, and IV was reduced and CIII had mild reduction in the patient compared to control. VDAC was used as loading control. ADC = apparent diffusion coefficient; DWI = diffusionweighted imaging; FLAIR = fluid-attenuated inversion recovery; ICU = intensive care unit; PROM = premature rupture of membranes; T2W = T2-weighted. 
Muscle biopsy sections stained for oxidative enzymessuccinate dehydrogenase (SDH) and combined in COX$\mathrm{SDH}$ showed reduced intensity (figure $1 \mathrm{D}, \mathrm{d}$ and e). Ultrastructurally, electron-dense inclusions were noted in mitochondria (figure 1Df). Respiratory chain complex assays showed an isolated deficiency of complex IV in the muscle (9.47\% of the normal mean value), and remaining complexes I (36.5\%), II (33.07\%), and III (147.06\%) were normal.

Exome sequencing showed a novel homozygous missense c.493 G>C (p.D165H) variation in ETHE1 (figure 1E), which was validated by Sanger sequencing. Both parents were heterozygous carriers (figure $1 \mathrm{E}$ ), suggesting an autosomal recessive mode of inheritance (figure e-1B; doi.org/10.5061/ dryad.6c9h1k7). This variation was highly conserved across the species (figure e-1C) and was predicted to be deleterious by in silico tools (Sorting Intolerant From Tolerant, PROVEAN, and Polyphen-2). This variation was not found in 180 healthy controls or the 1000 Genomes Project, Exome Aggregation Consortium (ExAC), or Genome Aggregation Database (gnomAD). Western blot analysis revealed low ETHE1 protein level in the patient (figure $1 \mathrm{~F}$ ). OXPHOS complex I (NDUFB8), II (SDHB), and IV (MTCO1) were markedly reduced, with mild reduction in complex III (UQCRC2) protein levels as compared to control (figure $1 \mathrm{~F}$ ).

\section{Discussion}

EE was first described in Italy and the causative gene, ETHE1, was identified in $2004 .^{1}$ It is located on chromosome 19 and encodes a member of the metallo- $\beta$-lactamase family containing iron proteins involved in the mitochondrial sulfur dioxygenase pathway. ${ }^{1,2}$ Since the identification of ETHE1, several point mutations and deletions have been described worldwide, with most patients belonging to Mediterranean or Arab ethnicity.

Patients with EE typically manifest with global delay and progressive neurologic deterioration leading to death within the first decade of life. ${ }^{1}$ The clinical course in our patient was marked by normal development up to 7 months of age, followed by periods of neuroregression. Atypical clinical features have been described, including intrafamilial variability. ${ }^{3-5}$ The characteristic features of $\mathrm{EE}$ noted in our patient included failure to thrive, seizures, spasticity, skin lesions, and worsening with intercurrent infection. Mucocutaneous manifestations arise from microvascular injury and include relapsing petechiae over the trunk, cutis marmorata over extremities, hemorrhagic suffusion over mucosal surfaces, and orthostatic acrocyanosis of distal extremities. ${ }^{1,5}$ Recurrent vomiting, hemorrhagic diarrhea, features of connective tissue disorder (vascular fragility and joint hyperextensibility), hydronephrosis, undescended testes, and cardiac anomalies are other systemic manifestations of EE. ${ }^{3}$ Brain MRI shows patchy hyperintense and enhancing lesions in basal ganglia typical of EE. ${ }^{2,3}$ Other reported abnormalities include hyperintensities of the brainstem, dentate nuclei, and cerebellar white matter, restricted diffusion, cortical atrophy, widened subarachnoid spaces, diffuse leukoencephalopathy, and congenital anomalies such as tethered cord and Chiari I malformation. ${ }^{2,5}$

The biochemical markers of EE include lactic acidosis, elevated C4\&C5 plasma acylcarnitines, and high EMA, isobutyryl glycine, and 2-methyl butyryl glycine in the urine. ${ }^{1}$ In our patient, the serum lactate level was persistently elevated, but urinary excretion of EMA and serum C4 and C5 acyl carnitines were normal. A report from Italy showed the absence of EMA during intercritical phases and the authors suggest that ETHE1 gene evaluation is required even in the absence of biochemical abnormalities. ${ }^{4}$ Accumulation of toxic compounds (sulfide) in EE causes inhibition of COX activity and degradation of COX subunits and mitochondrial dysfunction. ${ }^{1}$ In our patient, the enzyme activity of $\mathrm{SDH}$ and COX-SDH showed reduced intensity coupled with an isolated deficiency of complex IV activity in the skeletal muscle. Furthermore, the ultrastructural study showed presence of electron-dense inclusions within the matrix of mitochondria.

Exome sequencing analysis revealed a novel homozygous missense c. $493 \mathrm{G}>\mathrm{C}$ variation, leading to p.D165H of exon 4 in the patient, and the parents were heterozygous carriers. This variation is conserved and predicted to be pathogenic by in silico analysis. Western blot analysis for ETHE1 was low, suggesting impaired catalytic activity. OXPHOS protein complexes I, II, and IV were reduced significantly, with mild reduction of complex III protein levels. This suggested that the p.D165H variation resulted in OXPHOS dysfunction. It is important to establish an early diagnosis as it helps in prognostication.

The differential diagnoses of EE include many disorders in view of the overlapping clinical and biochemical findings. Clinically, EE has been shown to masquerade as a hematologic disorder, meningococcemia, connective tissue disorder, septic shock, and encephalitis because of the hemorrhagic lesions, diarrhea, encephalopathy, and articular hyperlaxity. Persistent ethylmalonic aciduria, apart from $\mathrm{EE}$, is noted in short-chain acyl-CoA dehydrogenase deficiency, glutaric aciduria type 2 , and some forms of mitochondrial respiratory chain enzyme deficiency. Precise diagnostic algorithm should be followed to differentiate these disorders from EE.

Multiorgan dysfunction in EE requires management by a team of specialists. Treatment is largely supportive and includes use of antispasticity medications, muscle relaxants, anticonvulsants, and early institution of physiotherapy to prevent contractures. Adequate nutrition and hydration should be ensured during diarrheal episodes. Partial benefit with riboflavin and coenzyme Q10 treatment has been reported. ${ }^{6}$ Diet restricted in sulfur-containing amino acids has been shown to improve the clinical outcome and biochemical markers. ${ }^{7}$ 
The combined use of metronidazole and $\mathrm{N}$-acetylcysteine has been used to control the $\mathrm{H}_{2} \mathrm{~S}$ overload, the toxic mechanism implicated in patients with EE. ${ }^{8} \mathrm{~N}$-acetylcysteine acts as a physiologic acceptor of the sulfur atom of $\mathrm{H}_{2} \mathrm{~S}$ while metronidazole reduces the sulfide producing bacterial load in the large intestine. Plasma thiosulfate levels could be determined to measure the adequacy of treatment. Continuous renal replacement therapy has been used to treat acute metabolic compensation. ${ }^{9}$ Orthotopic liver transplantation is emerging as a new therapeutic option for EE. ${ }^{2}$ Targeted adenoassociated virus-mediated ETHE1 gene transfer has been shown to improve both clinical course and metabolic abnormalities in a mouse model. ${ }^{10}$

We report a case of EE with a novel pathogenic variation c.493 $\mathrm{G}>\mathrm{C}(\mathrm{p} . \mathrm{D} 165 \mathrm{H})$ in ETHE1 with mild and inconsistent elevation of EMA and normal C4/C5 acylcarnitine. These findings support and expand the knowledge of the causative mutation in EE.

\section{Acknowledgment}

The authors thank the patient and his parents for participating in this study and Dr. Valeria Tiranti, Division of Molecular Genetics, IRCCS Foundation Neurological Institute "C. Besta," Italy, for providing ETHE1 antibody.

\section{Study funding}

This work was supported by the Science and Engineering Research Board, Department of Science and Technology, Government of India (grant PDF/2016/001625) awarded to P.G.

\section{Disclosure}

The authors report no disclosures relevant to the manuscript. Go to Neurology.org/N for full disclosures.

\section{Appendix Authors}

\begin{tabular}{lll}
\hline Name & Location & Contribution \\
\hline $\begin{array}{l}\text { Periyasamy } \\
\text { Govindaraj, PhD }\end{array}$ & $\begin{array}{l}\text { National Institute of } \\
\text { Mental Health and } \\
\text { Neurosciences } \\
\text { (NIMHANS), } \\
\text { Bengaluru, India }\end{array}$ & $\begin{array}{l}\text { Designed and } \\
\text { conceptualized study, } \\
\text { analyzed the data, } \\
\text { interpreted the data, } \\
\text { drafted the manuscript } \\
\text { for intellectual content }\end{array}$ \\
\hline Bindu Parayil & National Institute of & $\begin{array}{l}\text { Designed and } \\
\text { conceptualized study, } \\
\text { Sankaran, FRACP }\end{array}$ \\
& $\begin{array}{l}\text { Mental Health and } \\
\text { Neurosciences } \\
\text { (NIMHANS), } \\
\text { Bengaluru, India }\end{array}$ & $\begin{array}{l}\text { interpreted the data, } \\
\text { revised the manuscript } \\
\text { for intellectual } \\
\text { content }\end{array}$ \\
& &
\end{tabular}

Appendix (continued)

\begin{tabular}{|c|c|c|}
\hline Name & Location & Contribution \\
\hline $\begin{array}{l}\text { Madhu } \\
\text { Nagappa, DM }\end{array}$ & $\begin{array}{l}\text { National Institute of } \\
\text { Mental Health and } \\
\text { Neurosciences } \\
\text { (NIMHANS), } \\
\text { Bengaluru, India }\end{array}$ & $\begin{array}{l}\text { Major role in the } \\
\text { acquisition of clinical } \\
\text { data, drafted the } \\
\text { manuscript for } \\
\text { intellectual content }\end{array}$ \\
\hline $\begin{array}{l}\text { Hanumanthapura } \\
\text { R. } \\
\text { Arvinda, DM }\end{array}$ & $\begin{array}{l}\text { National Institute of } \\
\text { Mental Health and } \\
\text { Neurosciences } \\
\text { (NIMHANS), } \\
\text { Bengaluru, India }\end{array}$ & $\begin{array}{l}\text { Major role in the } \\
\text { acquisition of imaging } \\
\text { data }\end{array}$ \\
\hline $\begin{array}{l}\text { Sekar } \\
\text { Deepha, MSc }\end{array}$ & $\begin{array}{l}\text { National Institute of } \\
\text { Mental Health and } \\
\text { Neurosciences } \\
\text { (NIMHANS), } \\
\text { Bengaluru, India }\end{array}$ & $\begin{array}{l}\text { Major role in the } \\
\text { acquisition of laboratory } \\
\text { data }\end{array}$ \\
\hline $\begin{array}{l}\text { J.N. Jessiena } \\
\text { Ponmalar, MSc }\end{array}$ & $\begin{array}{l}\text { National Institute of } \\
\text { Mental Health and } \\
\text { Neurosciences } \\
\text { (NIMHANS), } \\
\text { Bengaluru, India }\end{array}$ & $\begin{array}{l}\text { Major role in the } \\
\text { acquisition of laboratory } \\
\text { data }\end{array}$ \\
\hline Sanjib Sinha, DM & $\begin{array}{l}\text { National Institute of } \\
\text { Mental Health and } \\
\text { Neurosciences } \\
\text { (NIMHANS), } \\
\text { Bengaluru, India }\end{array}$ & $\begin{array}{l}\text { Major role in the } \\
\text { acquisition of clinical } \\
\text { data }\end{array}$ \\
\hline $\begin{array}{l}\text { Narayanappa } \\
\text { Gayathri, PhD }\end{array}$ & $\begin{array}{l}\text { National Institute of } \\
\text { Mental Health and } \\
\text { Neurosciences } \\
\text { (NIMHANS), } \\
\text { Bengaluru, India }\end{array}$ & $\begin{array}{l}\text { Major role in the } \\
\text { acquisition of } \\
\text { histopathologic data, } \\
\text { revised the manuscript } \\
\text { for intellectual content }\end{array}$ \\
\hline Arun B. Taly, DM & $\begin{array}{l}\text { National Institute of } \\
\text { Mental Health and } \\
\text { Neurosciences } \\
\text { (NIMHANS), } \\
\text { Bengaluru, India }\end{array}$ & $\begin{array}{l}\text { Major role in the } \\
\text { acquisition of clinical } \\
\text { data, revised the } \\
\text { manuscript for } \\
\text { intellectual content }\end{array}$ \\
\hline
\end{tabular}

\section{References}

1. Tiranti V, D'Adamo P, Briem E, et al. Ethylmalonic encephalopathy is caused by mutations in ETHE1, a gene encoding a mitochondrial matrix protein. Am J Hum Genet 2004;74:239-252.

2. Dionisi-Vici C, Diodato D, Torre G, et al. Liver transplant in ethylmalonic encephalopathy: a new treatment for an otherwise fatal disease. Brain 2016;139:1045-1051.

3. Grosso S, Mostardini R, Farnetani MA, et al. Ethylmalonic encephalopathy: further clinical and neuroradiological characterization. J Neurol 2002;249:1446-1450.

4. Di Rocco M, Caruso U, Briem E, et al. A case of ethylmalonic encephalopathy with atypical clinical and biochemical presentation. Mol Genet Metab 2006;89:395-397.

5. Pigeon N, Campeau PM, Cyr D, Lemieux B, Clarke JT. Clinical heterogeneity in ethylmalonic encephalopathy. J Child Neurol 2009;24:991-996.

6. Yoon HR, Hahn SH, Ahn YM, et al. Therapeutic trial in the first three Asian cases of ethylmalonic encephalopathy: response to riboflavin. J Inherit Metab Dis 2001;24:870-873.

7. Boyer M, Sowa M, Di Meo I, et al. Response to medical and a novel dietary treatment in newborn screen identified patients with ethylmalonic encephalopathy. Mol Genet Metab 2018;124:57-63.

8. Viscomi C, Burlina AB, Dweikat I, et al. Combined treatment with oral metronidazole and $\mathrm{N}$-acetylcysteine is effective in ethylmalonic encephalopathy. Nat Med 2010;16:869-871.

9. Kitzler TM, Gupta IR, Osterman B, et al. Acute and chronic management in an atypical case of ethylmalonic encephalopathy. JIMD Rep 2019;45:57-63.

10. Di Meo I, Auricchio A, Lamperti C, et al. Virus-mediated gene therapy in a mouse model of ethylmalonic encephalopathy. EMBO Mol Med 2012;4:1008-1014. 


\title{
Neurology
}

\begin{abstract}
Child Neurology: Ethylmalonic encephalopathy
Periyasamy Govindaraj, Bindu Parayil Sankaran, Madhu Nagappa, et al.

Neurology 2020;94;e1336-e1339 Published Online before print February 28, 2020

DOI 10.1212/WNL.0000000000009144
\end{abstract}

This information is current as of February 28, 2020

\section{Updated Information \&} Services

References

Subspecialty Collections

Permissions \& Licensing

Reprints including high resolution figures, can be found at: http://n.neurology.org/content/94/12/e1336.full

This article cites 10 articles, 1 of which you can access for free at: http://n.neurology.org/content/94/12/e1336.full\#ref-list-1

This article, along with others on similar topics, appears in the following collection(s):

\section{All Genetics}

http://n.neurology.org/cgi/collection/all_genetics

All Movement Disorders

http://n.neurology.org/cgi/collection/all_movement_disorders

\section{All Pediatric}

http://n.neurology.org/cgi/collection/all_pediatric

Metabolic disease (inherited)

http://n.neurology.org/cgi/collection/metabolic_disease_inherited

Organic acid

http://n.neurology.org/cgi/collection/organic_acid

Information about reproducing this article in parts (figures,tables) or in its entirety can be found online at:

http://www.neurology.org/about/about_the_journal\#permissions

Information about ordering reprints can be found online:

http://n.neurology.org/subscribers/advertise

Neurology ${ }^{\circledR}$ is the official journal of the American Academy of Neurology. Published continuously since 1951, it is now a weekly with 48 issues per year. Copyright @ 2020 American Academy of Neurology. All rights reserved. Print ISSN: 0028-3878. Online ISSN: 1526-632X.

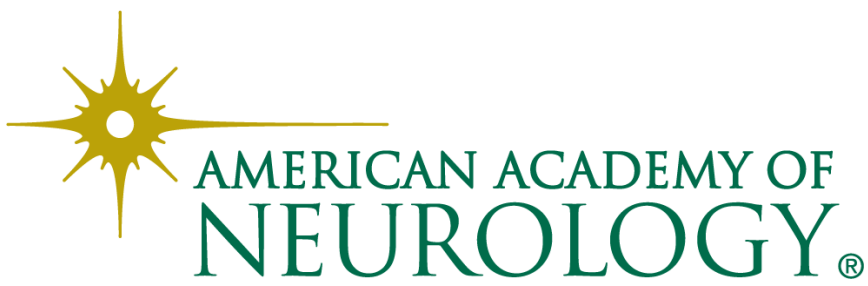

